\title{
Science, Technology and Innovation Management: Contributions to a Methodological Framework
}

\author{
Adriana Bin', Sergio Salles-Filhoa ${ }^{2}$
}

\begin{abstract}
The article discusses the specificities of science and technology development and innovation processes in organizational arena and their implications for planning and management. It proposes that ST\&I processes must be planned and managed as evolutionary processes defined by targeted attitudes to search routines and an understanding of the selective instances in which organizations are embedded, taking into consideration the distinct institutional elements that mediate such relations. To deal with this framework, the article proposes a methodological framework comprising a set of building blocks to help managers deal with the challenge of innovation. The building blocks are: (I) indeterminacy; (2) the profile of the professionals involved and the organizational culture; (3) the collective logic associated with the complexity of nonlinear, dynamic and adaptive systems; and (4) the logic of the scope economies associated with knowledge production. The methodology is applied in a case study of the Brazilian Agricultural Research Corporation, Embrapa.
\end{abstract}

Keywords: science; technology and innovation; research and development; management models; evolutionary processes; indeterminacy; complex systems; scope economies; embrapa

\footnotetext{
'Assistant professor, School of Applied Sciences, University of Campinas, R. Pedro Zacarias I300, Limeira, SP, Brazil - I3484-350 - phone: 55 I 970 I-6685 Email: adriana.bin@fca.unicamp.br. UNICAMP. Background in Food Engineering; Master and PhD in Scientific and Technological Policy. Researcher of the Study Group on the Organization of Research and Innovation - GEOPI.Areas of interest: planning and management of science, technology and innovation, strategic planning, research evaluation.

2Professor, Department of Science and Technology Policy, University of Campinas, POBox 6I 52, Campinas, SP, Brazil - I3083-870 - phone 5519 352। 4555 Email: sallesfi@ige.unicamp.br. UNICAMP. Background in Agronomic Engineering; Master in Energy Applied to Agriculture and PhD in Economics. Formerly Head of Planning of the National Agency for Innovation, FINEP. Presently is Director of the School of Applied Sciences at Unicamp. Founded, in 1995, the Study Group on the Organization of Research and Innovation - GEOPI.Areas of interest: economics, planning and management of science, technology and innovation.
}

ISSN: 07 I8-2724. (http://www.jotmi.org)

Journal of Technology Management \& Innovation (C) Universidad Alberto Hurtado, Facultad de Economía y Negocios. 


\section{Introduction}

One of the main debates within the management literature in recent years concerns the applicability of management practices and processes to a diverse range of organizations and activities. This discussion has pointed to some general conclusions. On the one hand, there is clear convergence to the extent that public and private organizations increasingly face common challenges and constraints. On the other hand, specificities arise when different activities are taken in account, in different cases, sectors and contexts (Mintzberg, 2009).

Among the challenges of this debate is the question of the specificities of managing science, technology and innovation (ST\&l) activities. New knowledge production and appropriation presents specificities that require special designs for management strategies and practices (Nowotny et al. 200 I). It is worthwhile to say that in spite of the possible differences between management efforts in ST\&I organizations in the public and private sector (as addressed by Damanpour and Schneider, 2008), activities such as research and innovation do require a proper and specific management approach (Tidd et al., 2005).

Thus organizations devoted to ST\&I activities have been building specific models designed to create favorable and competitive conditions for the fulfillment of their mission. Identifying the specificities of the management of those organizations and activities, as well as their practical consequences for the creation of these management models using a case study, is the main subject of this article.

Using concepts taken from the literature on the Economics of Technology and Innovation, and from other institutional approaches, the article proposes that the planning and management of research and innovation activities at organizations should be conducted on the basis of an evolutionary approach, defined by targeted attitudes to search routines and an understanding of the selective instances in which organizations are embedded. In short, this means conducting innovation management as something that must necessarily involve concepts and tools able to cope with environments and activities whose nature is evolutionary.

Given this conceptual framework, the article identifies four building blocks involved in research and innovation management: the ex ante indeterminacy of research and innovation activities; the profile (idiosyncrasies) of the professionals involved in those activities; the multi-institutional nature of complex adaptive systems (non-ergodic and self-organized systems); and the economies of scope that are in the very nature of knowledge production. The combination of these specificities generates the proposition of a limited set of methodological guidelines that can be used to design suitable management models.

The last section presents an application of the concepts and building blocks to the case of the largest research institution in Brazil, The Brazilian Agricultural Research Corporation (EMBRAPA).

\section{In pursuit of change: the evolutionary planning and management approach}

As an attempt to understand the specificities and premises that should guide the planning and management of ST\&I activities in the organizational sphere, we adopt the well-known concepts of search and selection (Nelson and Winter, 1982), both essential to the construction of an evolutionary approach to planning ST\&I activities. We will also address the concept of make or buy (Williamson, 1985; Williamson, 2010; Prahalad and Hamel, 1990; Glimstedt et al., 2012). It should be noted that although they were originally built to cope with ST\&I management in firms, the concepts presented below are useful for organizations in general, be they public or private.

The evolutionary approach, whose foundations are consolidated in An Evolutionary Theory of Economic Change (Nelson and Winter, 1982), centers on an understanding of economic change as an evolutionary process. This approach adopts the perspective that organizations have certain capabilities and decision-making rules, which change over time as a result of deliberate efforts to overcome problems and challenges. Also over time, organizations are submitted to selective instances that ultimately determine which of them can survive and grow (Teece, Pisano and Schuen, 1997; Teece, 2009; Winter, 2003).

The evolutionary approach understands organizations through their routines, which in spite of common sense are not static (Nelson and Winter, 1982; Dosi, 1982; Teece, Pisano and Schuen, 1997; Teece, 2009). For instance, Tranfield et al. (2003) show eight distinct types of routine that allow permanent change inside the organization and also entail an evolutionary perspective of the routine model. These types are: search, capture, articulate, contextualize, apply, evaluate, support and re-innovate.

Search, the second key concept, is a permanent activity undertaken by an organization to find ways of positioning itself better in its environment. Search is the movement an organization performs in order to introduce innovations. It is called search for two reasons: it is a deliberate procedure, and it is tentative. The organization experiments, creates expectations, believes in success, but cannot know whether it will in fact succeed until after the decision has been made and resources allocated. 
Hence the third key term in evolutionary theory: selection. All search procedures must lead to an instance of selection if they are to be successful in locating and implementing something considered valuable. Nelson and Winter (1982) define this instance as the market in capitalist economies, but it can also be any other ambience of validation.

Thus a simple but powerful principle governs how the decision-making process works: there is a logical separation between the search phase (what is expected) and the selection phase (what happens after the decision). In terms of management tools and methods, this perspective can be very useful (Teece, 2010).

This is the foundation for choosing between make or buy (Prahalad and Hamel, 1990; Glimstedt et al., 2012) and establishing the structures of coordination between the agents involved in those activities as well as their internal structures, demarcating their boundaries and strategically orienting their search efforts on that basis.

The analysis of internal and external competencies and the definition of more adequate governance structures are key to a better positioning of every organization. Many authors have explored the limitations of in-house R\&D (Teece, 2010; Pisano, 1990; Stanko and Calantone, 20II), the acquisition of innovation-complementary assets (Teece, 1986), or more recently the emergence of a movement of intense collaboration associated with knowledge creation (Benkler, 2002; Chesbrough, 2003; Chesbrough, 20I2, Aldrich, 20II) using this framework.

Integrated management of ST\&l activities is the link in the chain that brings together the planning and management of search procedures with those relating to selection. UItimately, to the extent that ST\&I planning and management involve evaluation and decision making in conditions of uncertainty and indeterminacy, their results are the alternatives chosen to orient the direction and form of execution of ST\&I processes, as well as the coordination structure for interaction among the various players involved.

Thus it is clear that if ST\&I processes in an organizational environment result from certain organizational and institutional formations which change over time, ST\&l planning and management are also characterized by this evolutionary component. Hence the idea is to create the conditions for evolutionary planning and management.

Planning and managing ST\&l is a typical case of "continuous planning problems" in which the agent has to permanently build and rebuild a sequence of actions in order to achieve an expected output or outcome. The idea of building an evolutionary planning model comes from Operational Research and from Artificial Intelligence, where genetic algorithms are proposed to deal with continuous planning problems (Zafar, Baig and Khan, 20l0). It is also a typical non-ergodic phenomenon (Davidson, 1991; Dequech, 201 I) where probabilities change along with (unforeseen) changes in the environment. As pointed out by Mol and Birkinshaw (2009) and Birkinshaw et al. (20l I), the main issues of interest in managing ST\&I are the conditions undertaken by firms to introduce new management practices and how they are associated with future returns. For the authors, the development of new products and new technologies is just the tip of the innovation iceberg, once there is a greater recognition that novel ideas can transform any part of the value chain, including management practices.

It is worthwhile to say that, in this view, not only ST\&I planning and management should be capable of dealing with specific evolutionary processes, but also they themselves must be considered evolutionary processes continuously submitted to selective instances. For planning purposes, building routines is as important as recognizing when and how to destroy them in order to allow new routines to emerge. This is the spirit of an evolutionary planning model.

\section{Building blocks for strategic management of ST\&I}

Approaching ST\&I activities as processes that create new ways to generate new value, rather than mere events, means introducing the idea that the factors that influence these processes can be manipulated so as to affect their results. This means, in summary, that they can be managed. In fact, the main challenge is how to identify such factors and how to handle them properly (Smith et al., 2008; Dodgson et al., 2008). Furthermore, ways to avoid redundancy and waste of resources must be considered in creative processes (as in any other process), as well as ways to foster the economies of scale and scope associated with ST\&I (Nelson, 199I; Nelson, 1996).

These aspects are increasingly important for any kind of organization, whether public, private or nonprofit. What we propose in this section is a set of building blocks that, we believe, can contribute to build a useful framework to deal with the specific challenge of innovation.

Four building blocks of ST\&I are highlighted: (I) indeterminacy; (2) the profile (idiosyncrasies) of the professionals involved; (3) the collective logic; and (4) the scope economies associated with knowledge production.

Indeterminacy is the key specificity of ST\&I activities and a component of uncertainty (Hronszky, 2005). In this paper we use a Keynesian approach to uncertainty as a natural condition of social systems. In this sense, uncertainty is not 
probabilistic (Davidson, 1991) but indeterminacy is. All future events are by nature uncertain, but there are different degrees of indeterminacy depending on the event.

Indeterminacy derives from two factors. The first is the nondeducibility of R\&D results, since any research effort (which will typically be innovative) may produce results of various kinds that go beyond or differ totally from what is expected (Rosenberg, 1982, 1994). The second is the time lag between research activities and effective use of their results, either as an input for other research or in terms of commercial or social appropriation (Kay, 1988; Stokes, 1997).

Although high indeterminacy is intrinsic to ST\&l (Hronszky, 2005), it may vary in intensity between the extremes of basic research and radical innovation or experimental development and incremental innovation (Dodgson et al., 2008; Latham and Braun, 2009).

Chang et al. (2007) and Brem and Voigt (2009) offer an additional perspective on indeterminacy, via the problem of managing the "front-end fuzziness" (FEF) inherent in innovation. For Chang et al. (2007), there are four dimensions to FEF: uncertainty, equivocality, complexity and variability, which together define an intrinsic inability to process relevant information for decision making in innovative processes.

To deal with indeterminate activities, it is preferable to have guidelines and premises of checking and re-checking than using some sort of "once for all" decision (Howells and James, 200I). That is why managers of ST\&I have developed and used tools like stage-gate, funnel, and real options: they allow them to re-check the performance of a previous decision under unforeseen conditions (Cooper, 201 I; Wouters et al., 20II).

The second element that differentiates ST\&I planning and management from other planning and management processes is the profile of the professionals involved, alongside the culture deriving from the norms and values associated with creation of the knowledge shared by these (idiosyncratic) professionals.

Generally speaking, the professionals who engage in research activities can be described as highly qualified and socially distinct, with a high level of creativity, curiosity and autonomy, all of which are crucial to intellectual work that requires a great deal of perseverance and independence. They are also intrinsically skeptical in the Mertonian interpretation, tending to question and critique a great deal (Jain and Triandis, 1997).

This question is often treated from the perspective of the intrinsic gap between scientists' individual goals and the objec- tives of organizations (Jain and Triandis, 1997; Coombs et al., 1989), which typically leads to conflicts between scientists and managers. In this regard, Birkinshaw et al. (20II) note that the most powerful motivators for innovation are typically "social" factors (such as the recognition and status conferred on those who do well) and "personal" factors (such as the intrinsic pleasure that some work affords).

Thus, a specific management of personnel is required. First because the peer recognition that permeates such activities define authority outside the boundaries of the organization, second because the indeterminate nature of the activities hinders performance evaluations based on results, and third because communication involves intellectual property hazards.

Smith et al. (2008), Adams et al. (2006) and Donate and Guadamilla (2010) show that, among other things, the management model has to foster the willingness to change, stimulate creativity and participation, and mitigate the impact of the "not-invented-here syndrome", as well as lay a foundation for adequate knowledge management (Jain and Triandis, 1997).

The third building block for ST\&I planning and management that differentiates it from other planning and management processes in the organizational sphere is the collective logic that derives from the fact that such activities are typically organized as complex systems.

Complex systems are understood here as non-linear, dynamic and adaptive systems. According to Dooley (1996) and Lichtenstein and McKelvey (20II), such systems have three key features: order as an emergent condition; the irreversibility of processes; and the unforeseeability of results. These elements were discussed above in connection with indeterminacy, but the difference here is the role played by agents as key elements of complex systems - agents understood as semi-autonomous units seeking to maximize benefits and opportunities and evolving over time (Faria, Lima and Santos, 2010).

For Gibbons et al. (I994, 20II) and Nowotny et al. (200I), the dynamics of science and research in contemporary society has been characterized by new mechanisms of knowledge creation that are more oriented to application and use, leading to a closer relationship with the creation and the social appropriation of knowledge. Thus knowledge production is increasingly integrated with knowledge use.

This perspective is complemented by the underlying logic of the idea of research networks, in which both the division of labor and information sharing are key to reducing costs and risks, while also extending access to knowledge and resources (Callon, 1992). Recently, this idea has been

ISSN: 07I 8-2724. (http://www.jotmi.org)

Journal of Technology Management \& Innovation (c) Universidad Alberto Hurtado, Facultad de Economía y Negocios. 
disseminated by Chesbrough $(2003,2012)$ in a discussion of what he calls open innovation.

While his approach does not introduce new concepts to characterize the nature of collaborative arrangements in research and innovation, it introduces two issues of particular interest: the (once again) hazards of intellectual property rights (Birkinshaw et al., 20I I; Alexy et al., 2009; Tao et al., 2010); and the necessity of inter-organizational management skills (the collective process involves many and different organizations).

The fourth building block that differentiates ST\&I planning and management is the intrinsic need to exploit the economies of scope (Panzar and Willig, 198I; Teece, 20I2) linked to knowledge production (Faria, Lima and Santos, 2010). The capacity to create new knowledge on a subject is directly linked to the learning conditions for those involved. The exchange of knowledge among people ineluctably has the capacity to produce more (new) knowledge.

When knowledge is acquired, it is immediately possible to formulate new knowledge that did not exist before and that is different from the sum of the original ideas. Better still, this process can be virtually infinite and there are factors that determine whether more or less knowledge can be produced about a given subject. Once this process is well organized, the results can be optimized.

In short, indeterminacy of results, the profile of the professionals involved, the collective logic of complex systems and the exploitation of scope economies are building blocks that can help those who work on ST\&I planning and management.

Generally speaking, it can be said that the key guideline for ST\&I planning and management is a conjunction of coordination and control with freedom and flexibility (Betz, 1987; Jain and Triandis, 1997; Sapienza, 2004).As many authors have proposed, the decision-making structure must consider flexibility in order to assure speed and functionality, and must have the ability to incorporate new routines in order to systematically capture and integrate apparently dispersed requirements and opportunities (Adams et al., 2006; Lam, 2006; Hidalgo and Albors, 2008; Hotho and Champion, 20 I0). Operationalizing such structures requires using the right planning and management approach. For Simon (1978), Simon et al. (1992) and March $(1978,2006)$ in their seminal studies of the problem of decision-making, the theoretical alternative to rational processes derives from perspectives that emphasize experience-based learning through adaptive processes (or so-called incremental or procedural rationality). This is the essence of an evolutionary management system and it has to take part of the corporate strategy (Tidd et al., 2005, Adams et al., 2006; Smith et al., 2008; Dodgson et al., 2008; Brem and Voigt, 2009). From the methodological standpoint, this reflection points to approaches that emphasize continuity, flexibility and intuition and also to formalized processes, implemented in a participatory manner so as to guarantee convergence and legitimacy.

Innovative organizations, whose core activity is R\&D for innovation, need to take coordination and control with freedom and flexibility into account. In recent years the public and private organizations that match this profile have followed a convergent path. Several authors have noted convergence in the planning and management practices of private and public organizations with a focus on R\&D and innovation (Arnold and Rush, 1996; Senker, 2000; Laredo and Mustard, 2004; Eisenberg, 2006; Salles-Filho and Bonacelli, 2010).

Instruments and practices for systematic science and technology prospecting conducted jointly with market prospecting, project management systems with portfolio programming and monitoring, mixed committees (with in-house and external personnel) to prioritize projects, systematic ex ante and ex post project evaluation, encouragement of research and innovation networks, competence in intellectual property, training in fund raising, and portfolio control, among others, are practices found today in research and innovation organizations of all types, whether public or private.

Of course, the public research organizations referred to here are of the mission-oriented type (health, space, agriculture etc.). Mission-oriented organizations clearly have innovation drivers, in that the scientific and technological research they conduct feeds into the development of products or services. The management models constructed by these organizations, as well as R\&D firms and private nonprofits, are very similar: they not only conduct high-level research and publish their findings in leading scientific journals, but are also committed to protecting the knowledge generated and to finding appropriate ways of getting it to users.

These organizations manage processes that involve indeterminacy and specific professional profiles (scientific and technological, besides those linked to the market), engage in collective development processes, and manage scope economies. Like any living organism, they are immersed in specific selective environments with specific criteria and indicators (Salles-Filho and Bonacelli, 2010).

The next section presents a case study in which the above concepts and building blocks are applied to the analysis of a research organization, Brazilian Agricultural Research Corporation (Embrapa). This application is the result of a recent study by the authors evaluating Embrapa's management model on the basis of recent trends in ST\&I planning and using the evolutionary approach. 


\section{Case Study: Embrapa's strategic management model}

Embrapa has won a worldwide reputation for research and innovation in tropical agriculture. Moreover, it has implemented different corporate planning and management models over the past 20 years, so that it can be considered an excellent candidate for a case study of the concepts and building blocks outlined above.

Embrapa is a state-owned enterprise established in 1973 by federal law and subordinated to the Ministry of Agriculture. Its mission is "to develop research and innovation in sustainable agriculture to benefit Brazilian society". Its operating structure consists of what it calls central units and decentralized units. It currently has 42 R\&D units across Brazil, 15 of which specialize in specific crops (such as soybeans, rice, dry beans, etc.), while ten pursue transverse lines of research in areas such as soils, instrumentation, agroenergy etc. It also has 17 regional centers for specific biomes (savannah or cerrado, pantanal, Amazon etc.) and five overseas laboratories known as Labex.

Embrapa is formally the lead institution in the National Agricultural Research System, which also includes state agricultural research organizations, federal and state universities and research institutions, and other public and private organizations directly or indirectly linked to the agricultural research sector.

The number of employees currently totals 9,242, of whom 2,215 are researchers (18\% with master's degrees, $74 \%$ with $\mathrm{PhDs}$ and $7 \%$ with postdoctoral qualifications). Its budget totaled some US\$I billion in $201 \mathrm{I}$.

Embrapa's central units comprise its highest management bodies, responsible for planning, supervising, coordinating and controlling activities relating to agricultural research and policymaking. Its decentralized units carry out the research, via linkages with producers and service providers.

As early as the 1980s Embrapa embarked on a planning initiative to support its efforts in this area. The first milestone in this process was the adoption of strategic planning as a core management practice and of the First Master Plan for the period 1988-92. According to Salles-Filho et al. (1997), strategic planning provided conceptual and methodological support for the process of change management and equipped the organization for the process of decision making on priorities in an environment full of external uncertainty.

The second milestone was the implementation of the Embrapa Planning System in 1992. Known by the acronym SEP, this was a formalized institutional model for organizing and managing research (core activity) and was the main output of the strategic planning initiative. The SEP indicated a transition from a technology-push to a demand-pull research model, a major shift compared with the traditional approach to agricultural research in Brazil. This was partly a reaction to external uncertainty, inasmuch as one of its goals was to change the way relationships were built with other actors and to establish closer ties with customers and users. Another goal was to set research priorities. All in all, it pointed to a model that was already approaching the Mode 2 of knowledge production (Nowotny et al., 200I).

Programming in the SEP was based on National R\&D Programs, thematic plans deriving from the priorities set by regional councils or at the national level. Projects and subprojects submitted by Embrapa's units had to match these plans.

It was also at this stage that Embrapa implemented monitoring and evaluation, again as part of the SEP.The highlight was SAPRE, a system of results-based evaluation and rewards that included SAU, a system for evaluating its research units, and also an evaluation of economic impacts in the agribusiness Brazilian scenario.

In 2002 SEP was replaced by the Embrapa Management System (SEG), as a result of the implementation of its Third Master Plan.Table I summarizes the key differences between the SEP and SEG in terms of the instruments used to operationalize programs and projects and to execute research.

The SEG was designed to implement a planning and portfolio structure that combined projects of greater density into networks oriented by major national themes, which were close to Mode 2 of knowledge production, with traditional R\&D projects of smaller size, associated more closely with Mode I.The result was a broad heterogeneous project portfolio. Embrapa's main concern in implementing the SEG was precisely to transition away from a fragmented model comprising individual projects with little interaction among the competencies of the decentralized research units. In addition, the SEG formalized the planning cycle processes.

The evaluation of Embrapa's management model was carried out in 2010 with the following scope:"evaluate the Embrapa Management System (SEG) by analyzing how the strategic, tactical and operational plans interact, and using indicators and metrics to measure its effectiveness and efficiency". The goal was to provide information to enable Embrapa to learn more about its functioning in the past eight years, the results achieved, and the prospects for its management system so that improvements could be made. 


\begin{tabular}{|c|c|c|}
\hline Item & $\begin{array}{l}\text { Sistema Embrapa de Planejamen- } \\
\text { to (SEP) }\end{array}$ & $\begin{array}{l}\text { Sistema Embrapa de Gestão } \\
(\mathrm{SEG})\end{array}$ \\
\hline Period & $1992-2002$ & 2002-now \\
\hline $\begin{array}{l}\text { Programmatic frame- } \\
\text { work }\end{array}$ & $\begin{array}{l}19 \text { National Programs ( } 16 \text { in } \\
\text { R\&D, } 3 \text { in institutional develop- } \\
\text { ment) }\end{array}$ & $\begin{array}{l}6 \text { Macro Programs ( } 3 \text { in } \mathrm{R} \& \mathrm{D}, 1 \\
\text { in technology transfer and com- } \\
\text { munication, } 1 \text { in institutional } \\
\text { development, } 1 \text { in family agricul- } \\
\text { ture) }\end{array}$ \\
\hline Programmatic focus & Research themes and lines & $\begin{array}{l}\text { Research networks; S\&T activi- } \\
\text { ties (basic and applied research, } \\
\text { experimental development) }\end{array}$ \\
\hline Research driver & Spontaneous demand for projects & $\begin{array}{l}\text { Project induction via requests for } \\
\text { proposals based on set thematic } \\
\text { lines (internal competitive funds) }\end{array}$ \\
\hline $\begin{array}{l}\text { Periodicity of prioriti- } \\
\text { zation }\end{array}$ & $\begin{array}{l}\text { Priorities set annually, based on } \\
\text { elements identified by advisory } \\
\text { council with assistance from out- } \\
\text { side members and aligned with } \\
\text { Master Plan }\end{array}$ & $\begin{array}{l}\text { Priorities set continuously, based } \\
\text { on an institutional agenda defined } \\
\text { by internal strategic collegiate } \\
\text { body and taking into account } \\
\text { elements identified by advisory } \\
\text { council with assistance from out- } \\
\text { side members and aligned with } \\
\text { Master Plan }\end{array}$ \\
\hline $\begin{array}{l}\text { Prioritization and se- } \\
\text { lection mechanism }\end{array}$ & $\begin{array}{l}\text { Collegiate bodies within each } \\
\text { National Program }\end{array}$ & $\begin{array}{l}\text { Collegiate bodies within decen- } \\
\text { tralized units and Macro Pro- } \\
\text { grams, in addition to collegiate } \\
\text { body responsible for global port- } \\
\text { folio resource allocation } \\
\end{array}$ \\
\hline $\begin{array}{l}\text { Integration of strategic } \\
\text { and operational sub- } \\
\text { systems }\end{array}$ & $\begin{array}{l}\text { Weak integration between strate- } \\
\text { gic and operational planning }\end{array}$ & $\begin{array}{l}\text { Management instruments for } \\
\text { integration of strategic and opera- } \\
\text { tional planning }\end{array}$ \\
\hline $\begin{array}{l}\text { Evaluation mecha- } \\
\text { nisms }\end{array}$ & $\begin{array}{l}\text { Institutionalization of economic } \\
\text { impact assessment for technolo- } \\
\text { gies generated; evaluation of pro- } \\
\text { ject outcomes }\end{array}$ & $\begin{array}{l}\text { Extension of impact assessment } \\
\text { to social and environmental } \\
\text { dimensions, as well as educa- } \\
\text { tion and training, in addition to } \\
\text { economic impact assessment and } \\
\text { project outcome evaluation }\end{array}$ \\
\hline
\end{tabular}

Table I: Key changes in Embrapa's management model 
The methodology entailed a comprehensive analysis of the documentation for all research planning and management processes, benchmarking of the management models used by comparable organizations in other countries, and analysis of Embrapa's management databases. Two workshops with a structured agenda were held, one with personnel external to the company and the other with internal personnel, and meetings were held to validate the results. Besides, circa 60 interviews with managers, researchers, and directors were performed. This process led to a detailed understanding of the model's potential and gaps, especially with regard to vertical and horizontal flows, linkages between the strategic, tactical and operational subsystems, participation and roles of the collegiate bodies involved in the management system, project portfolio, and IT structure.

Table 2 summarizes how the SEG's management instruments performed against the building blocks discussed in the previous section, based on the conceptual elements introduced in the first part of the paper.The point is to discuss how well Embrapa addresses the specificities of ST\&l in its planning and management structure and to note the main gaps in the model.

In sum, SEG manages indeterminacy reasonably well by constructing a management model that structures research projects consistently and over the long run while also being flexible enough to redirect projects or include new themes in the project portfolio. Embrapa has also made progress with the formalization of the planning process and management structure by making full use of the potential offered by the instruments at its disposal, which have sufficient adaptive capacity to address unforeseen or emergent factors. Another remark is the lack of internal guidelines in terms of specific tools to manage R\&D projects, like those that are developed to allow permanent revision and adjustments (stage-gates, real options and others). This way, indeterminacy could be better managed.

Regarding hierarchical issues, despite substantial efforts by Embrapa to prioritize demand and opportunities for research and innovation as part of its prospecting activities and in association with planning through management instruments, the value placed on scientific publication over and above other indicators ultimately rewards individual initiatives at the expense of coordinated actions associated with institutional priorities.

With regard to the complex collective management, the SEG has eventually produced a restricted collective logic: in spite of having created more dense projects (in terms of resources allocated per project) it has not made substantive progress in linking up with knowledge users. Participation by stakeholders in the productive sector still is limited. An important step forward in the SEG's development would be to make the productive sector a more active participant or even a shareholder in Embrapa's projects. Probably this is the main challenge in terms of increasing the economic and social impact from the results of its research projects.

Table 2: Embrapa management model and proposed building blocks

\begin{tabular}{|l|l|l|}
\hline $\begin{array}{l}\text { Building } \\
\text { block }\end{array}$ & SEG's strengths & SEG's weaknesses \\
\hline $\begin{array}{l}\text { Indetermi- } \\
\text { nacy }\end{array}$ & $\begin{array}{l}\text { Relatively flexible research planning } \\
\text { with continuous flow of RFPs capable } \\
\text { of systematically incorporating new } \\
\text { themes, requirements and opportuni- } \\
\text { ties (60 RFPs issued between 2002 } \\
\text { and 2009, covering some 530 lines of } \\
\text { research). }\end{array}$ & $\begin{array}{l}\text { Despite flexibility to incorporate } \\
\text { new themes and address challenges } \\
\text { in activity programming, SEG does } \\
\text { not contain sufficient monitoring } \\
\text { tools in operational dimension. Once } \\
\text { research projects are approved and } \\
\text { work has begun, there are no system- } \\
\text { atic monitoring instruments so that } \\
\text { projects with unsatisfactory results } \\
\text { can be redirected, adjusted or even } \\
\text { discontinued. Thus SEG deals with } \\
\text { indeterminacy only in strategic and } \\
\text { tactical dimensions, failing to do so in } \\
\text { operational dimension. }\end{array}$ \\
\hline
\end{tabular}

ISSN: 07 I8-2724. (http://www.jotmi.org)

Journal of Technology Management \& Innovation (C) Universidad Alberto Hurtado, Facultad de Economía y Negocios. 


\begin{tabular}{|c|c|c|}
\hline $\begin{array}{l}\text { Professional } \\
\text { profile }\end{array}$ & $\begin{array}{l}\text { Stimulates recognition of researchers } \\
\text { by scientific community, both encour- } \\
\text { aging them to attend science meetings } \\
\text { and above all considering scientific } \\
\text { production (especially publications in } \\
\text { indexed journals) a key performance } \\
\text { indicator in assessment of individual } \\
\text { researchers and units. } \\
\text { Grants researchers significant autono- } \\
\text { my provided they do work of scientif- } \\
\text { ic merit. This occurs via research lines } \\
\text { opened up by RFPs and possibility of } \\
\text { appropriating projects approved by } \\
\text { research funding agencies (external to } \\
\text { Embrapa), which account for about } \\
\text { 50\% of portfolio in terms of budget } \\
\text { resources. }\end{array}$ & $\begin{array}{l}\text { Deals adequately with core charac- } \\
\text { teristics of researchers' professional } \\
\text { profile in terms of scientific merit, but } \\
\text { lacks adequate indicators to measure } \\
\text { innovation. As a result, researchers } \\
\text { focus more on producing results that } \\
\text { can be published in journals than on } \\
\text { promoting effective use of technolo- } \\
\text { gies developed by productive sector, } \\
\text { which is ultimately Embrapa's mis- } \\
\text { sion. } \\
\text { Assuring strategic alignment of } \\
\text { portfolio is hindered by significant } \\
\text { autonomy granted to researchers } \\
\text { via research lines and appropriation } \\
\text { of projects with external funding. } \\
\text { Portfolio includes large number of } \\
\text { projects with little density in terms } \\
\text { of resources (some } 3,300 \text { projects in } \\
2010 \text { portfolio had US\$75,000 as an- } \\
\text { nual average). }\end{array}$ \\
\hline $\begin{array}{l}\text { Collective } \\
\text { logic }\end{array}$ & $\begin{array}{l}\text { Addressed mainly by encouraging } \\
\text { creation of research networks, espe- } \\
\text { cially in part of portfolio. Networks } \\
\text { focus mainly on relations between } \\
\text { Embrapa's internal units (located } \\
\text { throughout Brazil), partnerships with } \\
\text { universities (accounting for about } \\
42 \% \text { of total partnerships), technical } \\
\text { assistance and rural extension or- } \\
\text { ganizations (14\%), and other research } \\
\text { institutions (9\%). Less emphasis on } \\
\text { partnerships with private enterprise } \\
\text { and state-owned firms (9\%), farm } \\
\text { co-ops and associations (8\%), NGOs, } \\
\text { federal, state and municipal govern- } \\
\text { ments, foreign universities, and inter- } \\
\text { national agencies. }\end{array}$ & $\begin{array}{l}\text { Most networks focus on scientific } \\
\text { research, with little emphasis on in- } \\
\text { novation. Networks therefore work } \\
\text { in same direction as researchers (see } \\
\text { item on Professional Profile), i.e. S\&T } \\
\text { results-oriented rather than aim- } \\
\text { ing for effective use of output. Low } \\
\text { participation of productive sector } \\
\text { representatives is clear indication of } \\
\text { this weakness. }\end{array}$ \\
\hline
\end{tabular}




\begin{tabular}{|l|l|l|}
\hline $\begin{array}{l}\text { Economies of } \\
\text { scope }\end{array}$ & $\begin{array}{l}\text { Encouraging research networks } \\
\text { augments knowledge exchange and } \\
\text { sharing of competencies, resources } \\
\text { and risks. }\end{array}$ & $\begin{array}{l}\text { Despite synergies, managing networks } \\
\text { is highly challenging in terms of } \\
\text { financial and human resources as well } \\
\text { as communication between research } \\
\text { groups and real sharing of resources. } \\
\text { This point is particularly significant } \\
\text { for some large-scale projects with } \\
\text { more than 20 partners (internal and } \\
\text { external). }\end{array}$ \\
\hline
\end{tabular}

In terms of exploiting the economies of scope, Embrapa has planned for this to some extent, but it has not been significantly implemented. One of the key difficulties in connection with projects that display relatively high density of resources is finding forms of management capable of integrating activities and competencies by making them complementary, thus amplifying the impact of knowledge production.

To overcome the difficulties relating to indeterminacy, hierarchy and convergence between the efforts of different actors and to construct management models that leverage economies of scale and scope, Embrapa will have to foster the sharing of responsibilities between internal and external actors on the basis of common objectives and interests and to go one step ahead in the project management realm. This is still under construction and the corporation is now learning how to do it.

Actually, all these issues are not unknown to the company. Most of them are concerns that can already be found in the official documents and statements as well. The main issue now is to advance in its management model towards a real evolutionary one.

\section{Conclusions and further studies}

The analysis of Embrapa's management model shows a number of important steps forward in this direction. However, it is possible to say that the effort to create search routines in this institution greatly exceeds the effort to understand and manage selection instances, giving rise to gaps that hinder effectively integrated management. Thus while it cannot be denied that in recent years Embrapa has created advanced and efficient technologies thanks to the existence of a strong mechanism to prioritize research projects with a high level of scientific merit, some characteristics of a evolutionary management model still has to be developed. The monitoring and systematic evaluation of their outcomes (and by extension the organization's strategic orientation), and the sharing and division of tasks and competencies among the different actors in the productive (and innovative) sector, suggests there remain advances to be undertaken.
What is best practice in the management of research and innovation and how to implement it in the organizational context of public and private organizations? While there are common paths for the orienting of efforts and for search and selection, no single definitive management model can provide the answer, since the processes and tools selected must make sense historically and culturally for each organization. Focusing on indeterminacy, professional profile, the collective logic, and the necessary search for economies of scope, appear to make sense as an approach to the evaluation and design of different management models to suit different organizations. This is undoubtedly a possible and desirable way forward in pursuit of best practice in the management of innovation.

\section{Acknowledgements}

The authors wish to thank all the interviewees who took part in the evaluation project discussed in this paper and who generously shared their expertise and time, as well as the staff of Embrapa's Strategic Management and Research \& Development Departments.

\section{References}

ADAMS, R., Bessant, J., Phelps, R. (2006). Innovation management measurement: A review. International Journal of Management Reviews, 8(I), 2I-47.

ALDRICH, H. E. (20I I). An Evolutionary Approach to Entrepreneurship: Selected Essays by Howard E. Aldrich. Edward Elgar Publishing, Cheltenham.

ALEXY, O., Criscuolo, P., Salter, A. (2009). Does IP strategy have to cripple open innovation? MIT Sloan Management Review, 5I(I), 7I-77.

ARNOLD, E., Rush, H. (1996). Conclusions: challenges, lessons and success factors. In: Rush, H., Arnold, E., Bessant, J., Murray, R. Technology Institutes: Strategies for Best Practice. International Thomson Business Press, London. Pp. I74- 198.

ISSN: 07 I8-2724. (http://www.jotmi.org)

Journal of Technology Management \& Innovation (c) Universidad Alberto Hurtado, Facultad de Economía y Negocios. 
BENKLER, Y. (2002). Coase's penguin, or Linux and the nature of the firm. The Yale Law Journal, I I 2(3), 369-446.

BETZ, F. (1987). Managing Technology: competing through new ventures, innovation, and corporate research. PrenticeHall, Inc, New Jersey.

BIRKINSHAW, J., Bouquet, C., Barsoux, J. L. (20II). The 5 Myths of Innovation:Top 10 Lessons on the New Business of Innovation. MIT Sloan Management Review, 52(2), I-8.

BREM, A., Voigt, K. (2009). Integration of market-pull and technology-push in the corporate front end and innovation management: Insights from the German software industry. Technovation, 29(5), 35I-367.

CALLON, M. (1992). The dynamics of techno-economic networks. In: Coombs, R., Saviotti, P., Walsh, V. (Eds). Technological change and company strategies. Academic Press, London. pp. 72-102.

CHANG, S., Chen, C., Wey, S. (2007). Conceptualizing, assessing, and managing front-end fuzziness in innovation/NPD projects. R\&D Management, 37(5), 469-478.

CHESBROUGH, H. (2003). Open Innovation: the new imperative for creating and profiting from technology. Harvard Business School Press, Boston.

CHESBROUGH, H. (20I2). Open Innovation: Where We've Been and Where We're Going. Research-Technology Management, 55(4), 20-27.

COOMBS, R., Saviotti, P., Walsh, V. (1989). Economics and technological change. Macmillan, London.

COOPER, R. G. (20II). Perspective: The Innovation Dilemma: How to Innovate When the Market is Mature. Journal of Product Innovation Management, 28(SI), 2-27.

DAMANPOUR, F., Schneider, M. (2008). Characteristics of Innovation and Innovation Adoption in Public Organizations: Assessing the Role of Managers. Journal of Public Administration Research and Theory, 19(3), 495-522.

DAVIDSON, P. (I991). Is Probability Theory Relevant for Uncertainty? A Post Keynesian Perspective, Journal of Economic Perspectives 5(I), I29-I43.

DEQUECH, D. (20II). Uncertainty: A Typology and Refinements of Existing Concepts. Journal of Economic Issues, $45(3), 621-640$.
DODGSON, M., Gann, D., Salter, A. (2008). The management of technological innovation. Oxford University Press, Oxford.

DONATE, M.J., Guadamillas, F. (2010). The Effect of Organizational Culture on Knowledge Management Practices and Innovation. Knowledge and Process Management, I7(2), 8294.

DOOLEY, K. (1996). A Nominal Definition of Complex Adaptive Systems. The Chaos Network, 8(I), I-3.

DOSI, G. (1982). Technological paradigms and technological trajectories: a suggested interpretation of the determinants and directions of technical change. Research Policy, II (3), 147-162.

EISENBERG, R. S. (2006). Patents and data-sharing in public science. Industrial and Corporate Change, I5(6), I0I3-I03I.

FARIA, P., Lima, F., Santos, R. (2010). Cooperation in innovation activities: The importance of partners. Research Policy, 39(8), 1082-1092.

GIBBONS, M., Limoges, C., Nowotny, H., Schwartzman, S., Scott, P., Trow, M. (1994). The new production of knowledge: the dynamics of science and research in contemporary societies. Sage Publications Inc, London.

GIBBONS, M., Limoges, C., Scott, P. (20I I). Revisiting Mode 2 at Noors Slott. Prometheus: Critical Studies in Innovation, 29(4), 36I-372.

GLIMSTEDT, H., Bratt, D., Karlsson, M. P. (20I2). The Decision to Make-or-Buy a Critical Technology: semiconductors at Ericsson, 1980-20I0. In: Lazonick, W., Teece, D. J. (Eds.) Management Innovation: essays in the spirit of Alfred D. Chandler,Jr. Oxford University Press, New York. pp. 179-21 4.

HIDALGO, A., Albors, J. (2008). Innovation management techniques and tools: a review from theory and practice. R\&D Management, 38(2), I I3-I 27.

HOTHO, S., Champion, K. (2010). We are Always After that Balance: Managing Innovation in the New Digital Media Industry. Journal of Technology Management and Innovation, 5(3), 36-50.

HOWELLS, J., James, A. (200I). Corporate Decision-Making on the Sourcing of Technological Knowledge. Discussion Paper Series, Policy Research in Engineering, Science and Technology (PREST), University of Manchester. 
HRONSZKY, I. (2005). Mapping and managing uncertainty and indeterminacy in future society-technology relations. remarks on prospective technology analysis. In: Banse, G., Hronszky, l., Nelson, G. Rationality in an uncertain world. Sigma ed., Berlin. pp. 37-58.

JAIN, R.K., Triandis, H.C. (1997). Management of Research and Development Organizations: managing the unmanageable. John Wiley \& Sons Inc, New York.

KAY, N. (1988). The R and D function: corporate strategy and structure. In: Dosi, G., Freeman, C., Nelson, R., Silverberg, G., Soete, L. (Eds). Technical Change and Economic Theory. Pinter Publishers, London. pp. 282-294.

LAM, A. (2006). Organizational innovation. In: Fagerberg, J., Mowery, D.C., Nelson, R.R. (Eds). The Oxford Handbook of Innovation. Oxford University Press, Oxford. pp. I I5-I47.

LAREDO, P., Mustard, P. (2004). Public sector research: a growing role in innovation systems. Minerva, 42(I), I I-27.

LATHAM, S., Braun, M. (2009). Managerial Risk, Innovation, and Organizational Decline. Journal of Management, 35(2), 258-28I.

LICHTENSTEIN, B. B.; McKelvey, B. (20II). Four types of emergence: a typology of complexity and its implications for a science of management. International Journal of Complexity in Leadership and Management, I (4), 339-378.

MARCH, J. G. (1978). Bounded rationality, ambiguity, and the engineering of choice. The Bell Journal of Economics, 9(2), 587-608.

MARCH, J. G. (2006). Rationality, foolishness, and adaptive intelligence. Strategic Management Journal, 27(3), 20I-2I4.

MINTZBERG, H. (2009). Managing. Berrett-Koehler Publishers, San Francisco.

MOL, M., Birkinshaw, J. (2009). The sources of management innovation: When firms introduce new management practices. Journal of Business Research, 62(I2), I269-I 280.

NELSON, R. (1991). Why do firms differ, and how does it matter? Strategic Management Journal, 12(S2), 61-74.

NELSON, R. (1996). The sources of economic growth. Harvard University Press, London.

NELSON, R., Winter, S. (1982). An evolutionary theory of economic change. Harvard University Press, London.
NOWOTNY, H., Scott, P., Gibbons, M. (200I). Re-Thinking Science: Knowledge and the Public in an Age of Uncertainty. Polity Press, Cambridge.

PANZAR, J. C.,Willig, R. D. (198I). Economies of scope. The American Economic Review, 7 I (2), 268-272.

PISANO, G. (1990). The R\&D boundaries of the firm: an empirical analysis. Administrative Science Quarterly, 35(I), I53176.

PRAHALAD, C. K., Hamel, G. (1990). The core competence of the corporation. Harvard Business Review. 68(3), 79-9I.

ROSENBERG, N. (1982). Inside the Black Box: technology and economics. Cambridge University Press, Cambridge.

ROSENBERG, N. (1994). Exploring the Black Box: Technology, Economics, and History. Cambridge University Press, Cambridge.

SALLES-FILHO, S. L. M., Bonacelli, M. B. M. (20I0). Trends in the organization of public research institutions: lessons from Brasilian case. Science and Public Policy, 37(7), 193-204.

SALLES-FILHO, S., Albuquerque, R., Mello, D. (1997). Novos rumos da pesquisa agrícola e agroindustrial. In: Almeida, J., Navarro, Z. (Org). Reconstruindo a agricultura: idéias e ideais na perspectiva do desenvolvimento rural sustentável. Editora da UFRGS, Porto Alegre. pp. 189-203.

SAPIENZA, A.M. (2004). Managing Scientists: leadership strategies in scientific research. Wiley-Liss Inc, New Jersey.

SENKER, J. (2000). Introduction to a special issue on changing organisation and structure of European public-sector research systems. Science and Public Policy, 27 (6), 394-386.

SIMON, H. A. (1978). Rationality as process and as product of thought. The American Economic Review, 68(2), I-I6.

SIMON, H. A., Egidi, M., Vialle, R., Marris, R. (1992). Economics, Bounded Rationality and the Cognitive Revolution. Edward Elgar Publishing Limited, Cheltenhan.

SMITH, M., Busi, M., Ball, P., Van der Meer, R. (2008). Factors Influencing An Organisation's Ability To Manage Innovation:A Structured Literature Review And Conceptual Model. International Journal of Innovation Management, 12(4), 655-676.

STANKO, M.A., Calantone, R. J. (20I I). Controversy in Innovation Outsourcing Research: Review, Synthesis and Future Directions. R\&D Management, 4I(I), 8-20. 
STOKES, D. E. (1997). Pasteur's quadrant. The Brookings Institution Press, Washington.

TAO, L., Probert, D., Phaal, R. (20I0). Towards an integrated framework for managing the process of Innovation. R\&D Management, 40(I), 19-30.

TEECE, D. (1986). Profiting from technological innovation: implications for integration, collaboration, licensing and public policy. Research Policy, I5(6), 285-305.

TEECE, D. (2009). Dynamic Capabilities and Strategic Management. Oxford University Press Inc, New York.

TEECE, D. (2010). A Tribute to Oliver Williamson: Williamson's Impact on the Theory and Practice of Management. California Management Review, 52(2), 167-I76.

TEECE, D. (20I2). The Dynamics of Industrial Capitalism: perspectives on Alfred Chandler's Scale and Scope. In: Lazonick, W., Teece, D. J. (Eds.) Management Innovation: essays in the spirit of Alfred D. Chandler,Jr. Oxford University Press, New York. pp. 30-67.

TEECE, D. J., Pisano, G., Shuen,A. (1997). Dynamic capabilities and strategic management. Strategic Management Journal, 18(7), 509-533.

TIDD, J., Bessant, J., Pavitt, K. (2005). Managing Innovation: integrating technological, market and organizational change. John Wiley \& Sons Ltd, Chichester.

TRANFIELD, D., Young, M., Partington, D., Bessant, J., Sapsed, J. (2003). Knowledge Management Routines for Innovation Projects: developing a hierarchical process model. International Journal of Innovation Management, 7(I), 27-49.

WILLIAMSON, O. E. (1985). The economic institutions of capitalism: Firms, markets, relational contracting. Free Press, New York/London.

WILLIAMSON, O. E. (2010). Transaction Cost Economics: The Natural Progression. Journal of Retailing, 86(3), 2I 5-226.

WINTER, S. (2003). Understanding dynamic capabilities. Strategic Management Journal, 24(10), 991-995.

WOUTERS, M., Roorda, B., Gal, R. (201 I). Managing Uncertainty During R\&d Projects:A Case Study. Research-Technology Management, 54(2), 37-46.

ZAFAR, K., Baig, A. R., Khan, A. (2010). Collaborative Evolutionary Planning Framework (EPF) for Route Planning. International Journal of Computer Applications, 4(9), 33-38. 
J.Technol. Manag. Innov. 2012,Volume 7, Issue 2

ISSN: 07I8-2724. (http://www.jotmi.org)

Journal of Technology Management \& Innovation @ Universidad Alberto Hurtado, Facultad de Economía y Negocios. 